\title{
The Effect of Scoring during Flower Induction or the Initiation Phase on Return Bloom in Pyrus communis L.
}

\author{
L.P. Reynolds, G. Jacobs and K.I. Theron \\ Department of Horticultural Science \\ University of Stellenbosch \\ Private Bag X1 \\ Matieland, 7602 \\ South Africa
}

Keywords: flower quality, 'Doyenne du Comice', 'Rosemarie', 'Forelle', apical dominance and cytokinins

\begin{abstract}
The influence of scoring during the flower induction phase was investigated. Pear trees, Pyrus communis L. cv. Doyenne du Comice, Forelle and Rosemarie were used in the study, conducted in the Western Cape, South Africa. The yield of 'Doyenne du Comice' increased by $38 \%$ in scored trees compared to the control. The increase in yield was due to $50 \%$ more fruits on the scored trees than on the control trees. The increase in fruit number per tree was due to a higher percentage of reproductive buds per tree and the improved quality of these buds. Scoring of 'Rosemarie' at the correct time resulted in a $40 \%$ increase in reproductive buds. Scoring disrupts basipetal transport in the phloem, which results in the removal of apical dominance and an increase in root-derived cytokinins. More meristems can respond to inductive conditions and the higher concentration of cytokinins during inductive conditions leads to improved flower quality.
\end{abstract}

\section{INTRODUCTION}

A prerequisite for a large pear crop is the presence of a sufficient number of reproductive buds at the start of the season, but the quality of the flower cluster is equally important. Flower quality is measured in terms of its ability to set, retain and size fruit until harvest (Webster, 2002). To improve flower quality you need to increase the inflorescence size. Ferree et al. (2001) found a positive relationship between flower dryweight and fruit set and harvest fruit weight. There is, furthermore, a positive relationship between number of leaves and flowers in the inflorescence and fruit set (Lauri and Terouanne, 1999). Early bud development of apples is characterised by an increase in the number of appendages, i.e. bud scales, transition leaves and true leaves in the bud (Bijhouwer, 1924). Flower quality can be improved by earlier initiation, which will lead to a longer period of differentiation, or by increasing the rate of differentiation. Flower initiation is the first visible change of flower formation in the meristem, which, in pears, is seen as the broadening of the apex. Directly after flower initiation, flower differentiation follows, resulting in the formation of the different floral parts.

The aim of this study was to improve the inductive conditions for initiation, thereby increasing the number of reproductive buds initiated and also enhancing the process of initiation, which will result in better bud quality.

When the tree is scored at the start of flower initiation, the basipetal transport of auxin will be disrupted, which will lead to an increase in root-derived cytokinin (Li et al., 1995). This root-derived cytokinin should stimulate cell division in the developing reproductive bud, thereby raising the metabolic activity of the bud. Furthermore, the cytokinin can release meristems from apical dominance and therefore allow meristems to react to inductive conditions and become reproductive (Bangerth et al., 2000). 


\section{MATERIALS AND METHODS}

\section{Experiment 1}

1. Plant Material. Three pear cultivars, viz. Rosemarie, Forelle and Doyenne du Comice were used in this trial. 'Forelle' and 'Rosemarie' pear trees were from the Welgevallen Experimental Farm situated in the Stellenbosch area of the Western Cape, South Africa (34 $55^{\prime} \mathrm{S}$; 1 $\left.9^{\circ} 02^{\prime} \mathrm{E}\right)$. The 'Doyenne du Comice' pear trees were from a commercial orchard at Langrivier in the Koue Bokkeveld region of the Western Cape. The Western Cape is characterised by a Mediterranean climate: cold, wet winters and warm, dry summers. The Koue Bokkeveld region (1796 Richardson chill units) is a cooler region than the Stellenbosch region (500 Richardson chill units). The 'Forelle' trees planted on a Quince rootstock with a 'Beurré Hardy' interstock were planted in 1998 at a spacing of $3.8 \mathrm{~m} \mathrm{x} 1.25 \mathrm{~m}$ in a North-South row orientation. 'Kieffer' was used as the cross pollinator at a density of $10 \%$. The 'Rosemarie' trees were planted in 1992 at a spacing of $4.5 \mathrm{~m} \times 2.0 \mathrm{~m}$ with the same row orientation as the 'Forelle'. Both of these cultivars are trained to a 3-wire-trellis central leader system. 'Packham's Triumph' and 'Early Bon Chretien' were the cross pollinators at a density of $6.6 \%$ and $3.3 \%$, respectively. The 'Doyenne du Comice' on BP3 rootstock was planted in 1990, at a spacing of $4 \mathrm{~m} \mathrm{x} 1.5 \mathrm{~m}$ in an East-West row orientation. 'Packham's Triumph' trees were used as cross pollinator at a density of one branch per tree.

2. Methodology. The trees were scored $\pm 20 \mathrm{~cm}$ above the graft union by making use of a pair of citrus scoring pliers (Cape Agricultural Products Pty. Ltd.). The three wheels of the scoring pliers produce a narrow cut through the phloem and decrease the risk of cutting too deep into the cambium layer. The scoring is effective in inhibiting phloem transport for about two weeks. The trial was a randomised design with two treatments: (a) control and (b) scored treatment. A single tree was used as a replicate with 10 replications. The different cultivars were scored on the following dates:

- 'Rosemarie' scored on 29 November 2001 (79 days after full bloom, d.a.f.b.)

- 'Doyenne du Comice' scored on 30 November 2001 (56 d.a.f.b.) and 18 November 2002 (57 d.a.f.b.). The same trees were scored again $10 \mathrm{~cm}$ above the position used in the previous season.

- 'Forelle' scored on 12 December 2001 (88 d.a.f.b.)

\section{Experiment 2}

The same 'Rosemarie' orchard as used in Experiment 1 was used to evaluate the effect of time of scoring in 2002. A randomised block design was used with five treatments: (a) control, and scored on (b) 13 Nov., (c) 20 Nov., (d) 27 Nov., and (e) 4 Dec. Ten single trees were used as replicates. The scoring was done using the same method as described in Experiment 1.

\section{DATA COLLECTED}

\section{Experiment 1}

The total yield per tree was recorded at harvest in 2003. On a sample of 25 fruit per tree the following were determined for each fruit: (1) length, (2) diameter, (3) mass and (4) the seed content.

Fifteen one-year-old reproductive units (spurs) were tagged at random in spring 2001, on every replicate of each cultivar. These spurs differed: some bearing fruit, varying in number from one to three, and some where no fruit had set. On some units one or two well-developed bourse shoots formed, while others formed only bourse buds. The following data were recorded from these tagged units to determine differences in bourseover-bourse bearing tendency between the treatments. (1) The number of fruit harvested in 2002 and 2003, and the sizes and seed content of these fruit were determined. (2) The vegetative growth (bourse shoot) was measured and the number of leaves was counted.

(3) The number of reproductive buds initiated terminally on the bourse shoots was 
counted. The number of reproductive buds per potential bearing site (reproductive and vegetative buds) on three scaffold branches was recorded for the 'Doyenne du Comice' in the bloom of 2003 (return bloom).

\section{Experiment 2}

Random samples of two terminal spur buds were collected weekly per tree, on the different scoring dates, and these buds were dissected to monitor the bud development stage. The number of reproductive buds per potential bearing site (reproductive and vegetative buds) on three scaffold branches was recorded in the bloom of 2003 (return bloom).

\section{Statistical Analysis}

The data were analysed by the PROC GLM procedure in the SAS program (SAS, 1990).

\section{RESULTS}

\section{Experiment 1}

The scoring, 57 d.a.f.b., during the estimated flower initiation phase, resulted in a significant increase in the yield and the yield-efficiency (yield in $\mathrm{kg}$ per $\mathrm{cm}$ stem circumference) of 'Doyenne du Comice' (Table 1). In the case of 'Rosemarie' the increase in yield and yield-efficiency was not significant for the scored treatment compared to the control, but the same tendency, with an increase in yield for the scored treatment, as for 'Doyenne du Comice' was observed (Table 2). For the 'Forelle' there were no significant differences, nor tendency for an improvement in yield, between the two treatments (data not shown).

For the 'Doyenne du Comice' and the 'Rosemarie', the higher yield following the scoring treatment was due to a larger number of fruit harvested and not an increase in fruit size (Tables 1 and 2).

In the 'Doyenne du Comice' trees, the percentage of reproductive buds (return bloom in spring 2003) was increased significantly by the scoring treatment, even though the yield of the scored trees was $40 \%$ higher during the previous season (harvest 2003) (Table 1).

In all three cultivars the number of reproductive units (spurs) that resulted in bourse-over-bourse bearing was increased by scoring, but not significantly (data not shown). This was true for situations where a bearing bourse shoot was developed from a bearing unit, as well as a situation where the bearing unit gave a bourse shoot which had a terminal reproductive bud which flowered, but did not set (bourse-over-bourse flowering).

\section{Experiment 2}

The scoring treatments done on 'Rosemarie' led to the formation of $30 \%$ more reproductive buds than the control (Table 3). There was a linear decrease in the percentage reproductive buds from the earlier to the later scoring treatments (Table 3).

\section{DISCUSSION}

In Experiment 1 the scored 'Doyenne du Comice' and 'Rosemarie' trees produced a higher yield than the control (Tables 1 and 2). The higher number of fruit can be attributed to two factors.

Firstly, there could have been a higher percentage of reproductive buds (more flowers clusters). In Experiment 2 and in the return bloom of the 'Doyenne du Comice' in Experiment 1 it is clear that scoring can increase the percentage reproductive buds (Tables 1 and 3). It is also clear that the right timing to score the tree is critical. Experiment 2 showed that the earlier scoring treatments for the 'Rosemarie' resulted in the highest percentage reproductive buds, with a decline in percentage reproductive buds 
when the scoring was done later (Table 3). A possible reason is that with earlier removal of apical dominance more meristems can react to favourable conditions for initiation. Thus the scored 'Doyenne du Comice' trees of Experiment 1 formed 34\% more reproductive buds than the control. What makes this increase in reproductive buds more extraordinary is that the scored trees yielded $40 \%$ more fruit in the previous season compared to the control (Table 1). The higher percentage of reproductive buds could be caused by disruption of the basipetal auxin signal by scoring, resulting in the removal of apical dominance (Noël, 1970). Thus, more meristems were released from apical dominance and they could respond to inductive conditions and become reproductive.

Secondly, there could have been an improvement in the flower quality. This will lead to flowers that have a better potential to set and retain fruits. Flower quality is generally defined in terms of fertility, i.e. the capacity of flowers to respond to fruitsetting stimuli. Good quality flowers are those in which the stigmas remain receptive and the embryo sac stays viable for a long period of time, thereby increasing the chance for successful fertilisation (Williams, 1965). A good quality cluster has many flowers with short stalks, and a high tendency to set fruit. Flower pedicel length and dry weight, as well as flower dry weight, are positively related to harvest fruit weight and fruit set (Ferree et al., 2001). Lauri and Térouanne (1999) found a positive relationship between the number of flowers and fruit set. Flower quality is associated with the time in the season that the flower formed; strong blossoms are old, i.e. they were formed early in the previous season, while weak blossoms are young, i.e. formed late in the season.

Due to the scoring during flower initiation, the developing bud may receive a higher concentration of cytokinin. Cytokinins are known to stimulate cell division and thereby enhance metabolic activity. This implies that the sink strength of the developing bud will be enhanced, which will lead to an increase in auxin export and will ensure good vascular connection. The overall effect will be that flower differentiation will occur earlier and that the rate of flower differentiation will be enhanced. This will ultimately lead to more advanced reproductive buds.

In Experiment 1 the tagged units of the scored trees flowered more bourse-overbourse (bearing bourse over bourse plus flower bourse over bourse) than the control in all three cultivars, but not significantly so. The number of these bourse shoot flowers actually setting fruit was also higher for the scored treatment in 'Doyenne du Comice' and 'Forelle' compared to the control. These results support the argument that girdling leads to flowers of superior quality.

In Experiment 1 the effect of the scoring treatment was not as significant in the 'Rosemarie' as in the 'Doyenne du Comice'. One possible explanation for this is that flower initiation was earlier in the warmer climate of Stellenbosch than in the Koue Bokkeveld and therefore the timing of scoring the tree was too late in 2001. The warmer climate in Stellenbosch leads to earlier shoot growth cessation and shoot growth cessation is correlated with flower initiation (Reynolds et al., 2004; Tromp, 2000). Thus flower initiation in Stellenbosch is earlier than in the Koue Bokkeveld. The scoring was done on 28 and 29 November 2001 for the 'Rosemarie' and the 'Doyenne du Comice', respectively.

For the 'Forelle' in Experiment 1 there was no difference between the two treatments. Reasons for this could be that the timing of the scoring was too late. The 'Forelle' trees were scored 12 December 2001, which was two weeks later than the 'Rosemarie' (30 November 2001). It was clear from Reynolds et al. (2004) that 'Forelle's' flower initiation was two weeks earlier than in 'Rosemarie'. Furthermore, the total yield of the 'Forelle' orchard was very low, indicating other possible reasons for the low number of fruits. 


\section{CONCLUSION}

To conclude it is clear that scoring pear trees during the induction phase or at the start of flower initiation is highly beneficial for the cropping of the tree, but the timing of the scoring treatment is extremely important. It is highly likely that cytokinins play a role in the effect of the scoring.

\section{Literature Cited}

Bangerth, F., Li, C. and Gruber, J. 2000. Mutual interaction of auxin and cytokinins in regulating correlative dominance. Pl. Gr. Regul. 32: 205-217.

Bijhouwer, J. 1924. Die periodisiteit van de knopontwikkeling bij den appel. Meded. Landb. Hoogesch. Wageningen. 27: 1-64.

Ferree, D.C., Bishop, B.L., Schupp, J.R., Tustin, D.S. and Cashmore, W.M. 2001. Influence of flower type, position in the cluster and spur characteristics on fruit set and growth of apple cultivars. J. Hort. Sci. Biotech 76(1): 1-8.

Lauri, P.E. and Terouanne, E 1999. Effect of inflorescence removal on the fruit set of the remaining inflorescences and development of the laterals on one year old apple (Malus domestica Borkh.) branches. J. Hort. Sci. Biotech. 74(1): 110-117.

Li, C.J., Guevara, E., Herrera, J. and Bangerth, F. 1995. Effect of the apex excision and replacement by 1-naphthylacetic acid on cytokinin concentration and apical dominance in pea plants. Physiol. Plant. 94: 465-469.

Noël, A.R.A. 1970. The girdled tree. Bot. Rev. 36: 162-195.

Reynolds, L.P., Jacobs, G. and Theron, K.I. 2004. Reproductive bud development of pears (Pyrus communis L.) with emphasis on the bourse shoot. Acta Hort. (in press).

Richardson, E.A., Schuyler, D.S. and Walker, D.R. 1974. A model for estimating the completion of rest for 'Redhaven' and 'Elberta' peach trees. Hort. Sci. 9(4): 331-332.

SAS Institute Inc., 1990. SAS/STAT User's Guide, Version 6. $4^{\text {th }}$ ed. Vol. 1 and 2, Cary, NC, USA.

Tromp, J. 2000. Flower-bud formation in pome fruit as affected by fruit thinning. Pl. Gr. Regul. 31: 274-282.

Webster, A.J. 2002. Factors influencing the flower, fruit set and fruit growth of European pears. Acta Hort. 596(2): 699-709.

Williams, R.R. 1965. The effect of summer nitrogen application on the quality of apple blossom. J. Hort. Sci. 40: 31-41. 


\section{Tables}

Table 1. The effect of scoring, 57 d.a.f.b. in December 2001, on yield, yield-efficiency, average fruit weight and average fruit number for the harvest of 2003. The return bloom was determined at bloom 2003 (\% reproductive buds per potential bearing sites), after scoring 58 d.a.f.b. in 2002. The same 'Doyenne du Comice' trees of Langrivier, Koue Bokkeveld were used over two seasons.

\begin{tabular}{lccc}
\hline & Control & Scored & $\operatorname{Pr}>F$ \\
\hline Yield (kg fruit per tree) & $26.57^{\mathrm{a}}$ & $36.71^{\mathrm{b}}$ & 0.0384 \\
Efficiency (kg fruit per cm stem circumference) & $0.554^{\mathrm{a}}$ & $0.765^{\mathrm{b}}$ & 0.0259 \\
Average fruit weight $(\mathrm{g})$ & $184.80^{\mathrm{a}}$ & $169.81^{\mathrm{a}}$ & 0.1663 \\
Estimated average fruit number & $147.10^{\mathrm{a}}$ & $220.06^{\mathrm{b}}$ & 0.0131 \\
Return bloom & $35.19^{\mathrm{a}}$ & $47.27^{\mathrm{b}}$ & 0.0009 \\
\hline
\end{tabular}

Table 2. The effect of scoring 79 d.a.f.b. in November 2001 on yield, yield-efficiency, average fruit weight and average fruit number for the harvest of 2003 on 'Rosemarie', Welgevallen, Stellenbosch.

\begin{tabular}{lccc}
\hline & Control & Scored & $\operatorname{Pr}>F$ \\
\hline Yield (kg per tree) & $32.78^{\mathrm{a}}$ & $35.80^{\mathrm{a}}$ & 0.5284 \\
Efficiency (kg per cm stem circumference) & $0.8017^{\mathrm{a}}$ & $0.9063^{\mathrm{a}}$ & 0.3442 \\
Average fruit weight & $103.35^{\mathrm{a}}$ & $98.39^{\mathrm{a}}$ & 0.4548 \\
Estimated average fruit number & $322.87^{\mathrm{a}}$ & $371.10^{\mathrm{a}}$ & 0.3718 \\
\hline
\end{tabular}

Table 3. Percentage reproductive buds of total potential bearing sites in bloom 2003 for the different scoring treatments done in 2002.

\begin{tabular}{|c|c|c|c|c|c|c|c|}
\hline Treatments & $\mathrm{df}$ & Control & $\begin{array}{l}\text { Scored } \\
13 \text { Nov }\end{array}$ & $\begin{array}{l}\text { Scored } \\
20 \text { Nov }\end{array}$ & $\begin{array}{l}\text { Scored } \\
27 \text { Nov }\end{array}$ & $\begin{array}{c}\text { Scored } \\
4 \mathrm{Dec}\end{array}$ & $\operatorname{Pr}>F$ \\
\hline \% Reproductive buds & & $39.19^{c}$ & $52.98^{\mathrm{ab}}$ & $55.89^{\mathrm{a}}$ & $50.50^{\mathrm{ab}}$ & $46.06^{\mathrm{bc}}$ & 0.0014 \\
\hline \multicolumn{8}{|l|}{ Sig. Level } \\
\hline Control vs trt. & 1 & & & & & & 0.0004 \\
\hline Treat $*$ Linear & 1 & & & & & & 0.0422 \\
\hline Treat * Quadratic & 1 & & & & & & 0.1945 \\
\hline
\end{tabular}

